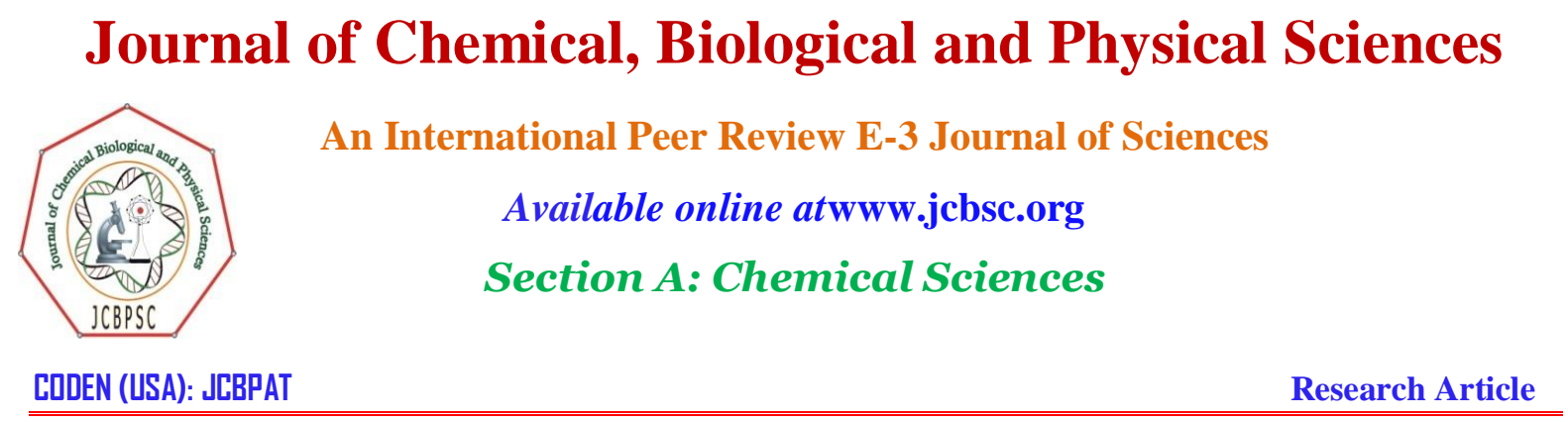

\title{
Synthesis and characterization of copper-caffeine complex for anti-bacterial studies using MIC method
}

\author{
Patil Rajashree. I' , Vidyasagar. C.C ${ }^{* 1}$, Kishore G. Bhat ${ }^{2}$ \\ ${ }^{1}$ Department of Chemistry, Rani Channamma University, Belgaum-591156, India \\ ${ }^{2}$ Department of molecular Biology \& Immunology Maratha Mandal's NGH Institute of Dental \\ Science\& Research Center, Belgaum-590010
}

Received: 13 August 2017; Revised: 23 August 2017; Accepted: 31 August 2017

\begin{abstract}
The interaction of caffeine with divalent copper ions was studied in aqueous solution. The resulting complexes were found to be crystalline and used to determine the cation binding mode and association constants, which are characterized using X-ray diffraction studies (XRD), fourier transform infrared spectroscopy (FTIR) and absorption spectra (UV-Visible). The investigation on the study of interaction between caffeine and $\mathrm{Cu}^{2+}$ ions and their molecular behavior shows significant change in the molecular interactions through metal hydration shell. Especially ligand like caffeine can incredibly interact with metal and capable of altering the conformation of structure. The metal binding interaction of caffeine is quite useful to understand the molecular interaction with $\mathrm{Cu}^{2+}$ when they are targeted upon a bacterial growth. As a copper is an electron acceptor it trims down the capacity of growth of bacteria and fungus, which implies the reduction in bacterial growth. Aspergillus flavus fungus has the less capacity to substitute oxygen with alternative oxidisable compounds as terminal electron acceptor in respiration by showing highly sensitive up to $0.2 \mathrm{gm} / \mathrm{L}$. However, biological implications point to the importance of knowing the characteristic of metal ion complexation in water solution and therefore more sensitive technique should be used.
\end{abstract}

Keywords: Aspergillus, Antibacterial, Caffeine, Copper-complex 


\section{INTRODUCTION}

Caffeine is an alkaloid, a class of naturally occurring drugs containing nitrogen and having the properties of an organic amine base including theophylline and theobromine, which belongs to a family of naturally occurring compounds known as xanthenes. Caffeine has side-effects include toxicity in excess of consumption, high adrenal simulation are present in different ratios in the different plant sources for example caffeine is found in coffee, tea, cola, muts, mate and guarana. Caffeine is a plannar aromatic molecule which leads to the hypothesis that it could very easily form $\pi-\pi$ complexes with transition metal ions ${ }^{1-3}$. Caffeine is a vasodilator (relaxes the blood vessels) as well as a diuretic (increases urination). Caffeine does not exist alone in coffee or tea leaves, the leaves are mainly cellulose pigments and chlorophylls, and tannins. Tannic are phenolic compounds of high molecular weight. The acidic phenols of tannins can complex with metals like calcium to form solid precipitates ${ }^{4}$.

Biological Role of Copper: Copper plays an important role in our metabolism, largely because it allows many critical enzymes to function properly. Copper is essential for maintaining the strength of the skin, blood vessels, epithelial and connective tissue throughout the body. Cu plays a role in the production of hemoglobin, myelin, melanin and it also keeps thyroid gland functioning normally. Copper can act as both an antioxidant and a pro-oxidant. Free radicals occur naturally in the body and can damage cell walls, interact with genetic material, and contribute to the development of a number of health problems and diseases. As an antioxidant, $\mathrm{Cu}$ scavenges or neutralize free radicals and may reduce or help prevent some of the damage they cause. When copper acts as a pro-oxidant at times, it promotes free radical damage and may contribute to the development of Alzheimer's disease. Maintaining the proper dietary balance of $\mathrm{Cu}$, along with other minerals such as zinc and manganese, is important ${ }^{5}$. This caffeine has the ability to form complexes with metal ions from nd series. Caffeine contains some nitrogen, oxygen atoms involved in coordinative bonds. The transition metal ions and their complexes take part for all the fundamental biologic process oxygen, nitrogen fixation and transformation, coordination of all metabolic reactions, catalysis and bio-photo catalysis, solar energy, molecular electrons etc. pharmaceutical scientists are currents facing an increasing treatment with less ideal properties such as poor solubility and lack of acceptable physical and chemical stability ${ }^{6}$. The metal complexes of caffeine have considerable interest in the design of model complexes, which showed significant antiinflammatory activity, antitumor activity and different animal cancer ${ }^{7-9}$. Some caffeine complexes were found biologically active such as the complexes [ $\left.\mathrm{PPh}_{3} \mathrm{Me}\right],\left[\mathrm{PtCl}_{3}\right.$ (caffeine)], [ $\mathrm{Ac}_{2} \mathrm{Zn}$ (caf)] $\mathrm{H} 2 \mathrm{O}$ and $\left[\mathrm{Cu}\right.$ (pyridine) (caf)] have anticancer, antifungal and antimicrobial activity ${ }^{10}$.

\section{MATERIALS AND METHODS}

All reagents were purchased commercially and used without further purification. Coffee was purchased from and $\mathrm{CuCl}_{2}$ was procured from Merck, Mumbai. Dichloromethane and Anhydrous sodium sulfite were procured from HI Media, Mumbai. All solvents used were analytical grade and double-distilled water was used throughout the experiment.

Extraction of Caffeine from Coffee: In a typical extraction, coffee powder $(10 \mathrm{gm})$ stirred vigorously with $200 \mathrm{ml}$ of distilled water at $40{ }^{\circ} \mathrm{C}$. the resultant solution was kept undisturbed for 30 min till the mixture attains ambient temperature. On continue cooling in an ice bath, the coffee solution must be cooled bellow $20{ }^{\circ} \mathrm{C}$ before coming contact with dichloromethane (Boiling point$\left.40{ }^{\circ} \mathrm{C}\right)$ then extracted the solution three times with $30 \mathrm{ml}$ portions of Dichloromethane $\left(\mathrm{CH}_{2} \mathrm{Cl}_{2}\right)$. 
<smiles>Cn1c(=O)c2c(ncn2C)n(C)c1=O</smiles>

Fig.1: Structure of caffeine

Extraction Step: The coffee solution is poured in to a separating funnel and $20 \mathrm{ml}$ of dichloromethane is added to it. The mixture will be separated in to two layers, the top layer is coffee solution and the bottom layer is dichloromethane since it is the denser than coffee solution. Shake the separating funnel and vent the separating funnel periodically to release the vapor pressure created inside. When the contents have been sufficiently shaken and placed the separating funnel back on the ring stand and allowed the two layers for separation. Then the layer was drained in to conical flask because now caffeine is extracted in to the dichloromethane layer. Cover the mouth of conical flask to avoid the evaporation of solution. Similar procedure has been followed twice and dried the combined dichloromethane solution with anhydrous sodium sulfite. Then one tea spoon of drying agent was added and stirred well and kept undisturbed for 10 min (Fig. 2).

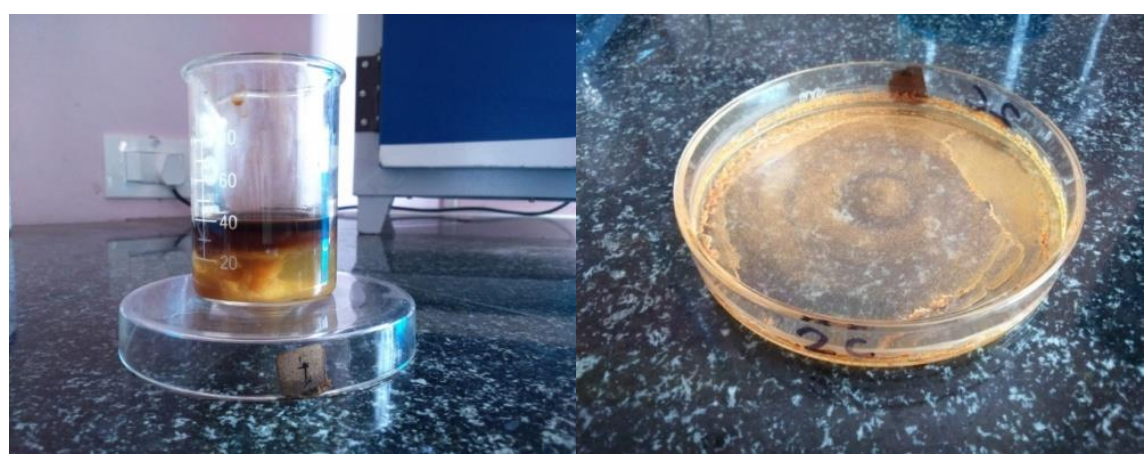

Fig. 2: Extraction of caffeine from coffee

The resultant decant with dichloromethane was collected in to conical flask and kept it for evaporation of the dichloromethane solvent at $30{ }^{\circ} \mathrm{C}$ on hot water bath, which lead to brownish crystalline caffeine.

Preparation of copper-caffeine complex: In a typical synthesis of copper-caffeine complex, the preparation of complexes was found to be solids, insoluble in most common organic solvents such as chloroform, acetone and acetonitrile but soluble in DMS. A $0.5 \mathrm{M}$ of $\mathrm{Cu}(\mathrm{OH})_{2}$ solution was prepared by one-step prepetition method using $0.5 \mathrm{M} \mathrm{NaOH}$. An ethanolic solution $15 \mathrm{ml}$ of caffeine was added to an aqueous solution of the $\mathrm{Cu}(\mathrm{OH})_{2}$ under constant stirring at ambient temperature for $8 \mathrm{~h}$. Then the resultant solution was taken into Petridish and dried at $50{ }^{\circ} \mathrm{C}$ by moderate heating for $2 \mathrm{~h}$. Figure 3 shows the addition of caffeine into aqueous $\mathrm{Cu}(\mathrm{OH})_{2}$ solution at ambient temperature. The same procedure has been followed for the preparation of copper-caffeine 


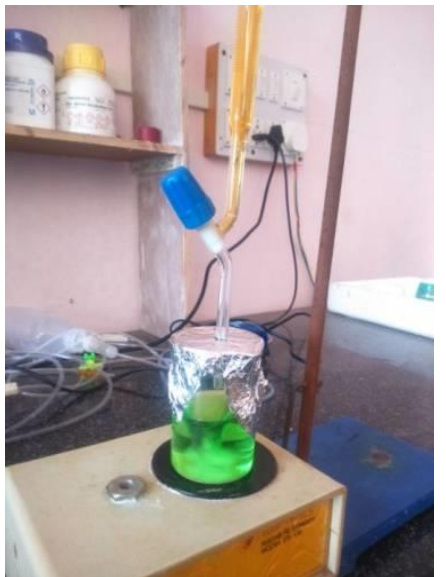

Fig.3: Formation of caffeine-copper complex solution

complexes at different concentrations $\left(\mathrm{R}_{1}=0.2 \mathrm{gm}\right.$ caffeine in $25 \mathrm{ml}$ distilled water and $0.5 \mathrm{M} \mathrm{CuCl}_{2}$ in $0.5 \mathrm{M} \mathrm{NaOH}),\left(\mathrm{R}_{2}=0.3 \mathrm{gm}\right.$ caffeine in $25 \mathrm{ml}$ distilled water and $0.5 \mathrm{M} \mathrm{CuCl}_{2}$ in $\left.0.5 \mathrm{M} \mathrm{NaOH}\right)$ and $\left(\mathrm{R} 3=0.4 \mathrm{gm}\right.$ caffeine in $25 \mathrm{ml}$ distilled water and $0.5 \mathrm{M} \mathrm{CuCl}_{2}$ in $\left.0.5 \mathrm{M} \mathrm{NaOH}\right)$. Similar procedure has been followed for the preparation of caffeine and also copper as follows, and named as $R_{1}, R_{2}, R_{3}$.

\section{A. UV-Vis Analysis}

Figure 4 exhibit the UV-Vis absorption spectra of bare Caffeine, $\mathrm{CuO}, \mathrm{CuCl}_{2}$ and $\mathrm{Cu}-\mathrm{Caffeine}$ complex compounds in the range of 200 to $600 \mathrm{~nm}$. The optical absorption of bare Caffeine, $\mathrm{CuCl}_{2}$ and $\mathrm{CuO}$ were found to be around 363, 279 and $264 \mathrm{~nm}$ (Fig. 4a, b, c), respectively. All CuCaffeine samples (Fig. 4d, e, f) of different concentration of $\mathrm{Cu}$ ions added were found to be at the optical absorption ability in the longer wave length region with maximum absorption, which illustrate the gradual red shift as the implantation concentration of $\mathrm{Cu}$ ions increased (Fig. 4).

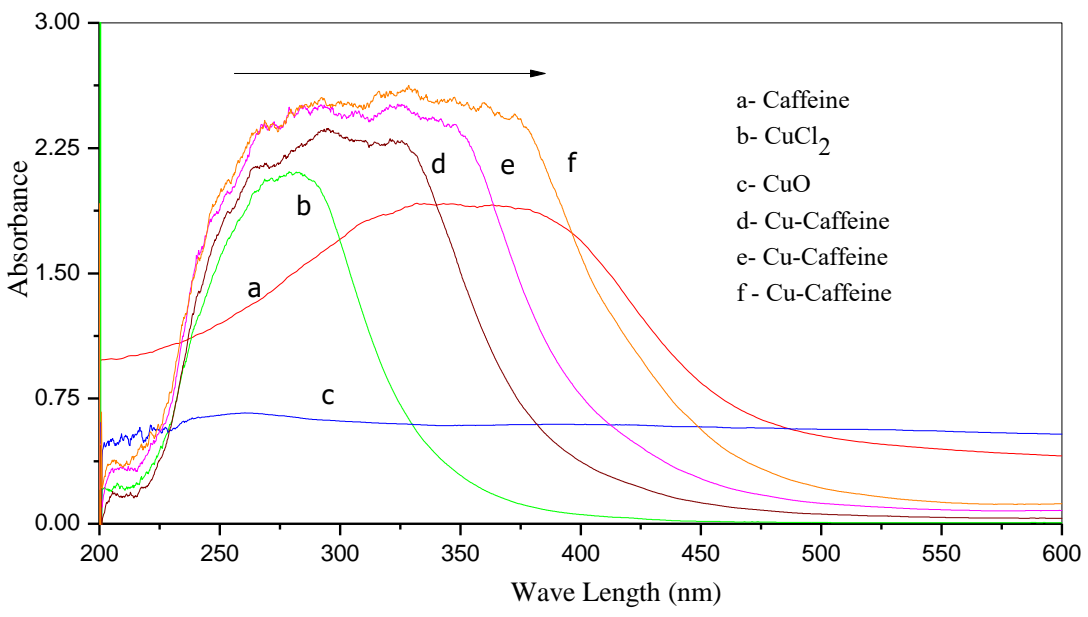

Fig.4: UV-Vis Absorption spectra of copper-caffeine complexes

Since the possible change in the spectra of $\mathrm{Cu}$-Caffeine complexes compared to bare caffeine, $\mathrm{CuCl}_{2}$ and $\mathrm{CuO}$ samples, which imply the probability chance of formation of complex between $\mathrm{Cu}$ ions and caffeine. As the concentration of $\mathrm{Cu}$ ions increased $\mathrm{UV}$-Vis spectra were originated towards longer wave length region with increasing absorption. This is because of increase in the electron density of bonding electrons at conduction band of the Caffeine molecule, which forms covalent bond between $\mathrm{Cu}$ ion and caffeine and change in the energy of the lowest unoccupied 
molecular orbital (LUMO), causing of $\pi-\pi^{*}$ and $d \pi-\pi^{*}$ transitions to occur at higher or lower energies as well as the metal-to-ligand charge transfer (MLCT) absorption at lower energy region.

\section{B. XRD analysis}

The XRD spectra (red) were obtained for caffeine $\left(\mathrm{R}_{0}\right)(\mathbf{F i g} . \mathbf{5})$ is well aligned to the literature and fits for the same ${ }^{11}$. The major peaks $\left(\mathrm{R}_{1}\right)$ located at $2 \theta$ values correspond to the characteristic of monoclinic phase of $\mathrm{CuO}$ (JCPDS NO80-1268) due to low concentration of caffeine in the complex. No other peaks were observed belonging to any impurity such as $\mathrm{Cu}(\mathrm{OH})_{2}$ and $\mathrm{Cu}_{2} \mathrm{O}$, indicating high purity of $\mathrm{CuO}$ nanoparticles $\left(\mathrm{R}_{1}\right)$. Because of low concentration of caffeine, caffeine might not be observed in the XRD pattern. At higher concentration of $\mathrm{Cu}$ and caffeine, we observe shift in peak position and slight increase in the peak intensities (highlighted in Stars) illustrate the implementation of caffeine with $\mathrm{Cu}$ (Green- $\mathrm{R}_{1}$, Blue- $\mathrm{R}_{2}$ and Pink- $\left.\mathrm{R}_{3}\right)$. We observed the appearance of caffeine peaks (according to the literature) in $\mathrm{Cu}$-Caffeine complexes in terms of change in peak positions, which are shifted slightly towards lower and higher $2 \theta$ angles and decrease in fringe width at half maximum (FWHM) are because of complex formation between the $\mathrm{Cu}$ and caffeine, respectively. The intensities also found to be increased supplementary $R_{3}$ compare to $R_{1}, R_{2}$ and $R_{0}$ for $\mathrm{Cu}-\mathrm{Caffeine}$ complex compare to bare $\mathrm{CuO}\left(2 \theta=10\right.$ to $\left.25^{\circ}\right)$.

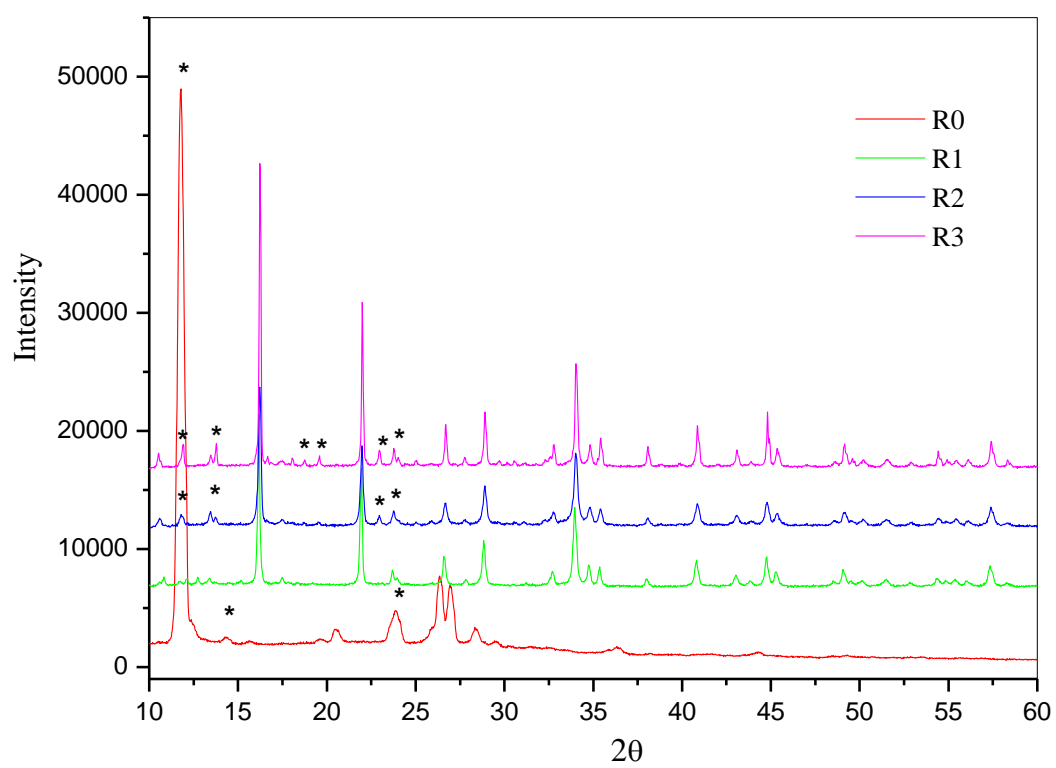

Fig. 5: X-ray diffraction spectra of copper-caffeine complexes

\section{IR spectrum analysis}

The IR spectra obtained for caffeine indicates four major peaks (Fig. 6). Absorption at $3426 \mathrm{~cm}^{-1}$ indicates presence of amine group. The absorption at $1761 \mathrm{~cm}^{-1}$ indicates presence of ketone group and absorption of $1658 \mathrm{~cm}^{-1}$ indicates alkene parts of molecule. Absorption at $974 \mathrm{~cm}^{-1}$ indicates aromatic carbon absorption. The IR spectra of copper-caffeine complex show four major peaks (Fig.7).Absorption at $3458 \mathrm{~cm}^{-1}$ presence of amine group with slight moisture content and absorption at $1637 \mathrm{~cm}^{-1}$ shows ketone group. The band at $670 \mathrm{~cm}^{-1}$ (finger print region) indicates metal ion peak and absorption at $2360 \mathrm{~cm}^{-1}$ indicates $\mathrm{C}-\mathrm{N}$ stretching frequency ${ }^{10-14}$. The IR spectrum obtained shows absorption at $3420 \mathrm{~cm}^{-1}$ indicates presence of amine group (Fig. 8). Absorption at 


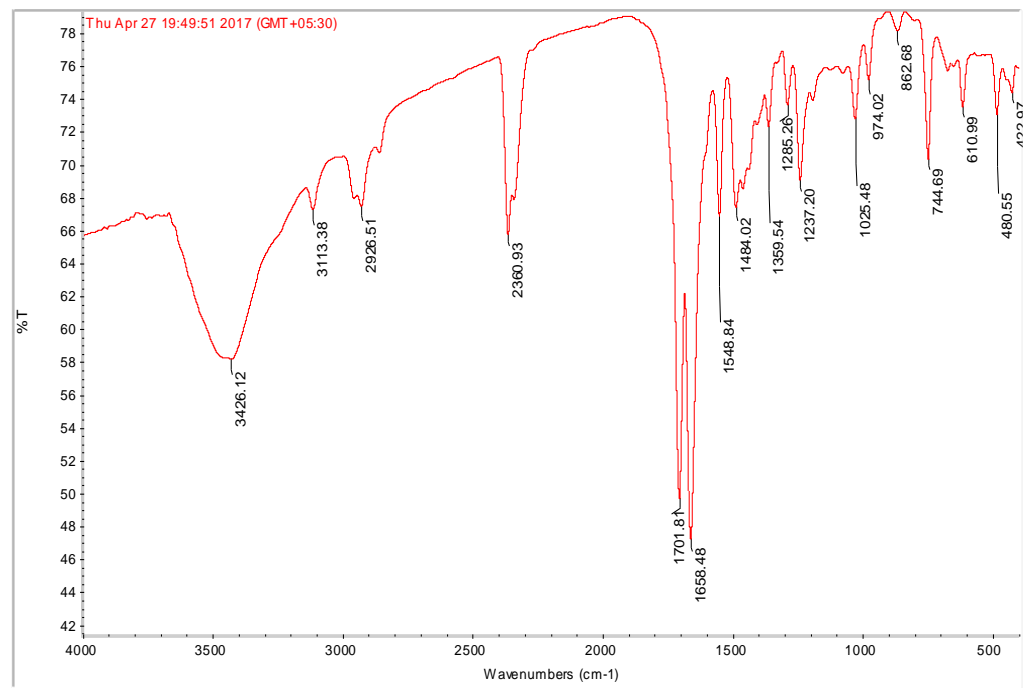

Fig.6: IR Spectra of bare caffeine $\left(\mathrm{R}_{0}\right)$

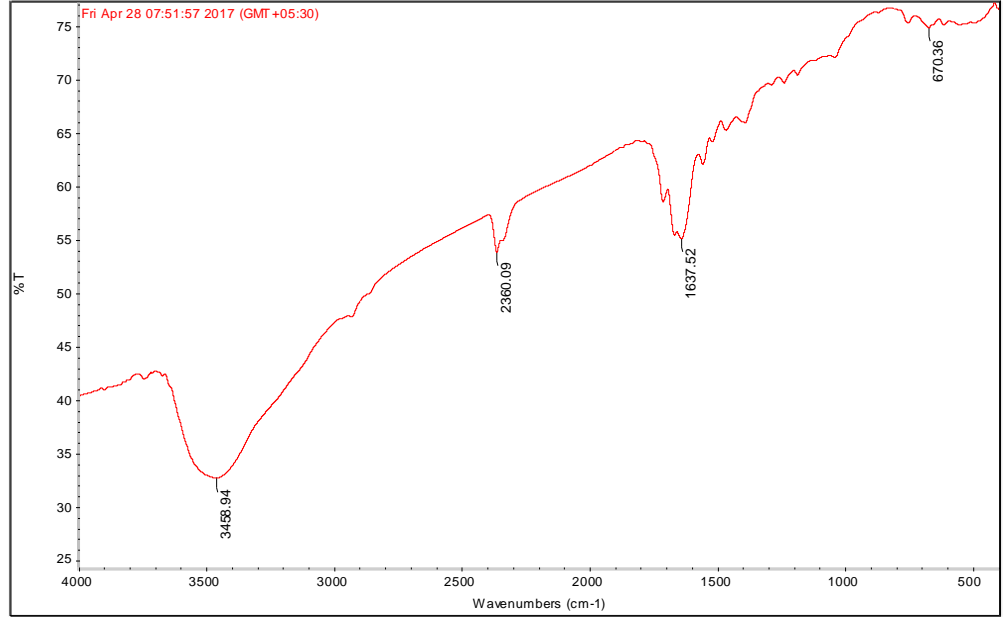

Fig.7: IR Spectra of caffeine copper complex $\left(\mathrm{R}_{1}\right)$

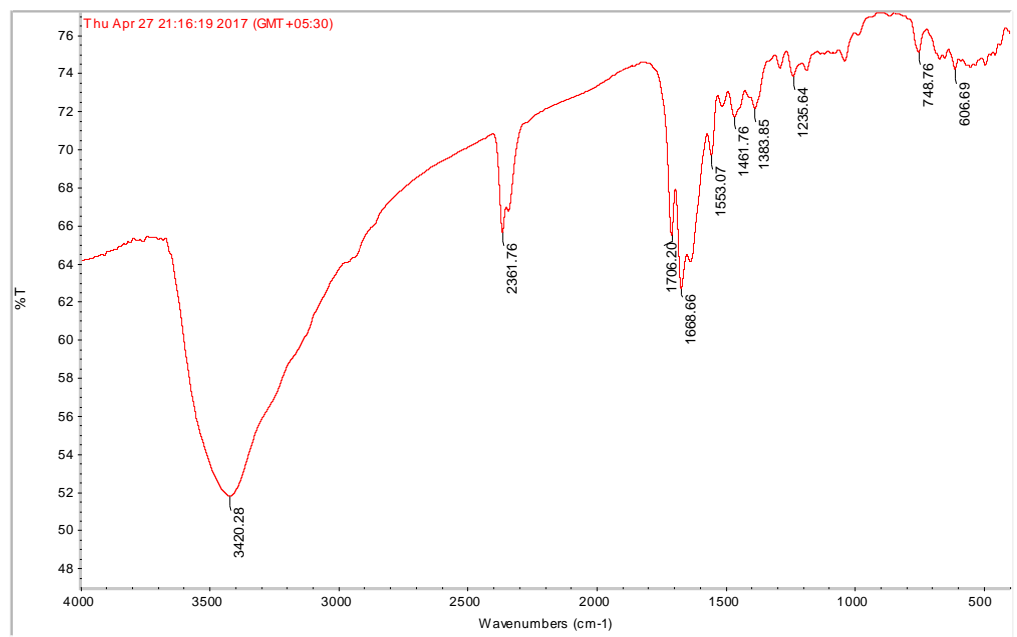

Fig.8: IR Spectra of caffeine copper complex $\mathrm{R}_{2}$ 
Ketone. Absorption at $748 \mathrm{~cm}^{-1}$ indicates presence of metal ion. The IR spectra obtained at 3424 $\mathrm{cm}^{-1}$ indicates presence of amine group (Fig. 9). Absorption at $2279 \mathrm{~cm}^{-1}$ indicates C-N stretching frequency. Absorption at $1706 \mathrm{~cm}^{-1}$ shows carbonyl group as ketone. Absorption at $1400-1500 \mathrm{~cm}^{-1}$ shows methyl type of group. Absorption at $750 \mathrm{~cm}^{-1}$ shows presence of metal ion (Fig. 7, 8, 9).

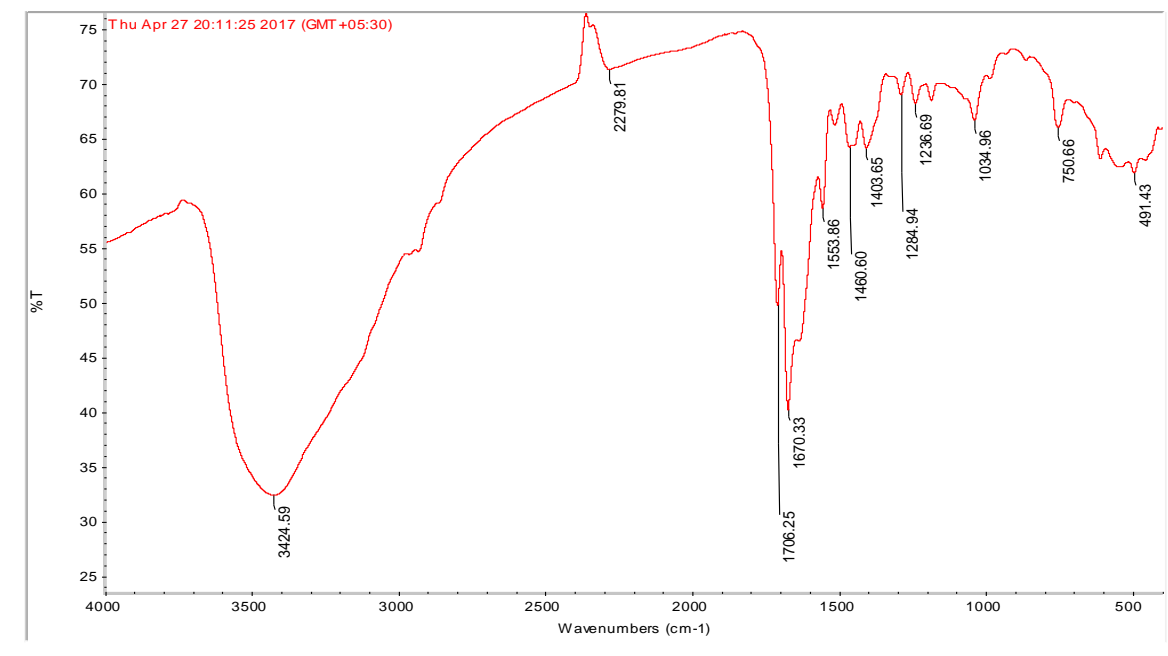

Fig.9: IR Spectra of caffeine copper complex $\left(\mathrm{R}_{3}\right)$

\section{Biological activity studies by MIC method}

MIC occurrence and multiplicity is more potential when microorganisms are active in water below 0,9. However, water is not enough; growth requires always an electron donor, which is oxidized, an electron acceptor, which is reduced with energy and a carbon source. According to these requirements, they are grouped systematically. Microorganisms implicated in MIC of metals such as iron, copper and aluminum, and their alloys are physiologically diverse. Bacteria involved in metal corrosion have frequently been grouped by their metabolic demand for different respiratory substrates or electron acceptors. The capability of many bacteria to substitute oxygen with alternative oxidisable compounds as terminal electron acceptors in respiration, when oxygen becomes depleted in the environment, permits them to be active over a wide range of conditions conducive for corrosion of metals. The ability to produce a wide spectrum of corrosive metabolic by-products over a wide range of environmental conditions makes microorganisms a real threat to the stability of metals that have been engineered for corrosion resistance.

\section{E. Biological activity analysis}

In a typical MIC procedure 9 dilutions of each drug have to be done with BHI (brain heart infusion) for MIC. In the initial tube 20 microliter of drug was added into the 380 microliter of BHI broth. Soon after 200 microliter of BHI broth was added into the next 9 tubes separately. Then as of the initial tube 200 microliter was transferred to the first tube containing 200 microliter of BHI broth, which was considered as $10^{-1}$ dilution. From $10^{-1}$ diluted tube 200 microliter was transferred to second tube to make $10^{-2}$ dilution. The serial dilution was repeated up to $10^{-9}$ dilution for each drug. From the maintained stock cultures of required organisms, 5 microliter was taken and added into 2 $\mathrm{ml}$ of BHI (brain heart infusion) broth. In each serially diluted tube, 200 microliter of above culture suspension was added. Finally tubes were incubated for 24 hours and observed for turbidity. As the concentration was decreased bacillus bacteria showed activity, which implies sensitivity till 12.5 
$\mathrm{mg} / \mathrm{ml}$. Hence this point to first three tubes was like clear solution and further more confirmed turbidity. Aspergillus flavus shows sensitivity till the $0.04 \mathrm{mg} / \mathrm{ml}$, hence it shows obvious solution like water, hence no turbidity was found. Resistivity shows turbidity as like in ASPERGILLUS NIGER, BACTERIA BACILLUS, but ASPERGILLUS FLAVUS shows sensitivity to the drug towards copper-caffeine complex for the biological assay.

\section{Chemical and physical data of Caffeine}

\begin{tabular}{|ll|}
\hline Formula & $\mathrm{C}_{8} \mathrm{H}_{10} \mathrm{~N}_{4} \mathrm{O}_{2}$ \\
\hline Molar mass & $194.19 \mathrm{~g} / \mathrm{mol}$ \\
\hline Density & $1.23 \mathrm{~g} / \mathrm{cm}^{3}$ \\
\hline Melting point & 235 to $238^{\circ} \mathrm{C}\left(455^{\circ} \mathrm{F}\right.$ to $\left.460{ }^{\circ} \mathrm{F}\right)$ \\
\hline IUPAC Name & $1,3,7-$ Trimethylpurine-2, 6-Dione \\
\hline Bioavailability & $99 \%$ \\
\hline Protein binding & $25-36 \%$ \\
\hline Biological half-life & Adults \\
\hline & Neonates \\
\hline Metabolites & Paraxanthiene- $84 \%$ \\
\hline & Theobromine-12\% $\mathrm{h}$. \\
\hline & Theophyline- $4 \%$ \\
\hline Duration of Drug action- & $3-4$ h. \\
\hline Drug class & Stimulant \\
\hline Drug ingredient & Caffeine citrate \\
\hline
\end{tabular}

\section{MIC RESULTS}

\begin{tabular}{|c|c|c|c|c|c|c|c|c|c|c|}
\hline E.coli & $\mathbf{1 0 0} \boldsymbol{\mu g} / \mathbf{m l}$ & $\mathbf{5 0}$ & $\mathbf{2 5}$ & $\mathbf{1 2 . 5}$ & $\mathbf{6 . 2 5}$ & $\mathbf{3 . 1 2}$ & $\mathbf{1 . 6}$ & $\mathbf{0 . 8}$ & $\mathbf{0 . 4}$ & $\mathbf{0 . 2}$ \\
\hline $\mathrm{R} 1$ & $\mathrm{~S}$ & $\mathrm{~S}$ & $\mathrm{R}$ & $\mathrm{R}$ & $\mathrm{R}$ & $\mathrm{R}$ & $\mathrm{R}$ & $\mathrm{R}$ & $\mathrm{R}$ & $\mathrm{R}$ \\
\hline $\mathrm{R} 2$ & $\mathrm{~S}$ & $\mathrm{~S}$ & $\mathrm{R}$ & $\mathrm{R}$ & $\mathrm{R}$ & $\mathrm{R}$ & $\mathrm{R}$ & $\mathrm{R}$ & $\mathrm{R}$ & $\mathrm{R}$ \\
\hline $\mathrm{R} 3$ & $\mathrm{~S}$ & $\mathrm{~S}$ & $\mathrm{~S}$ & $\mathrm{R}$ & $\mathrm{R}$ & $\mathrm{R}$ & $\mathrm{R}$ & $\mathrm{R}$ & $\mathrm{R}$ & $\mathrm{R}$ \\
\hline
\end{tabular}

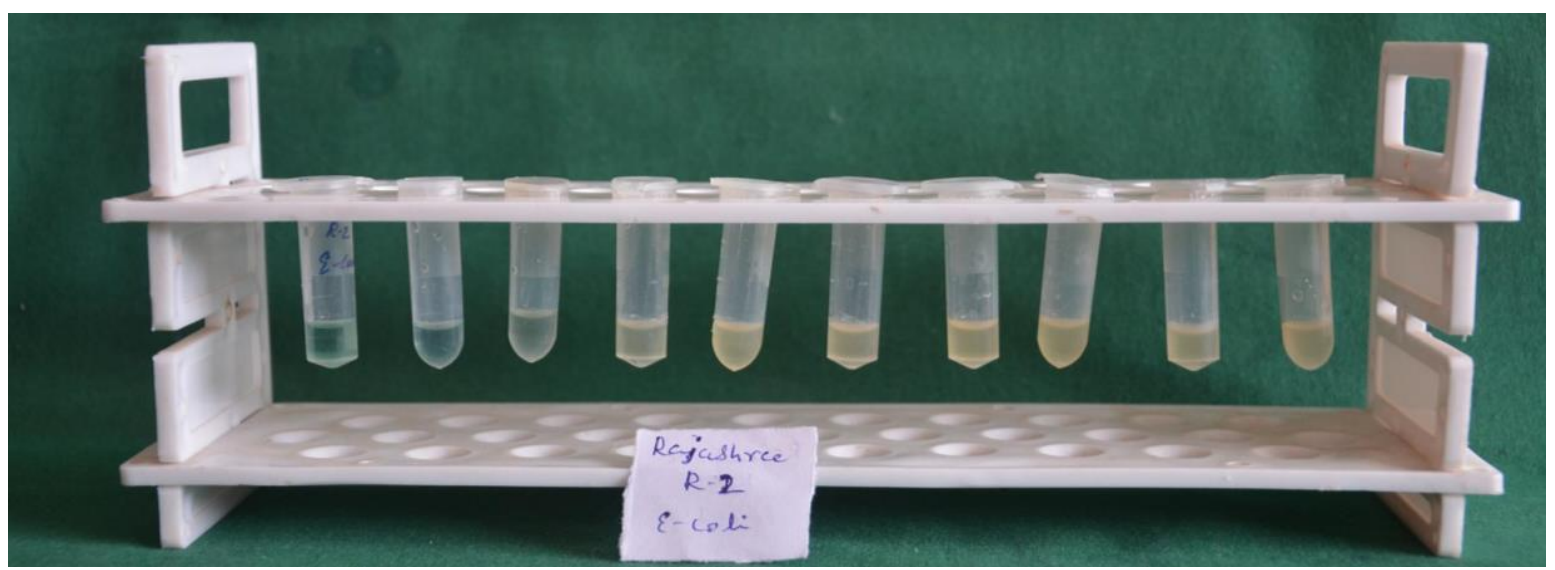




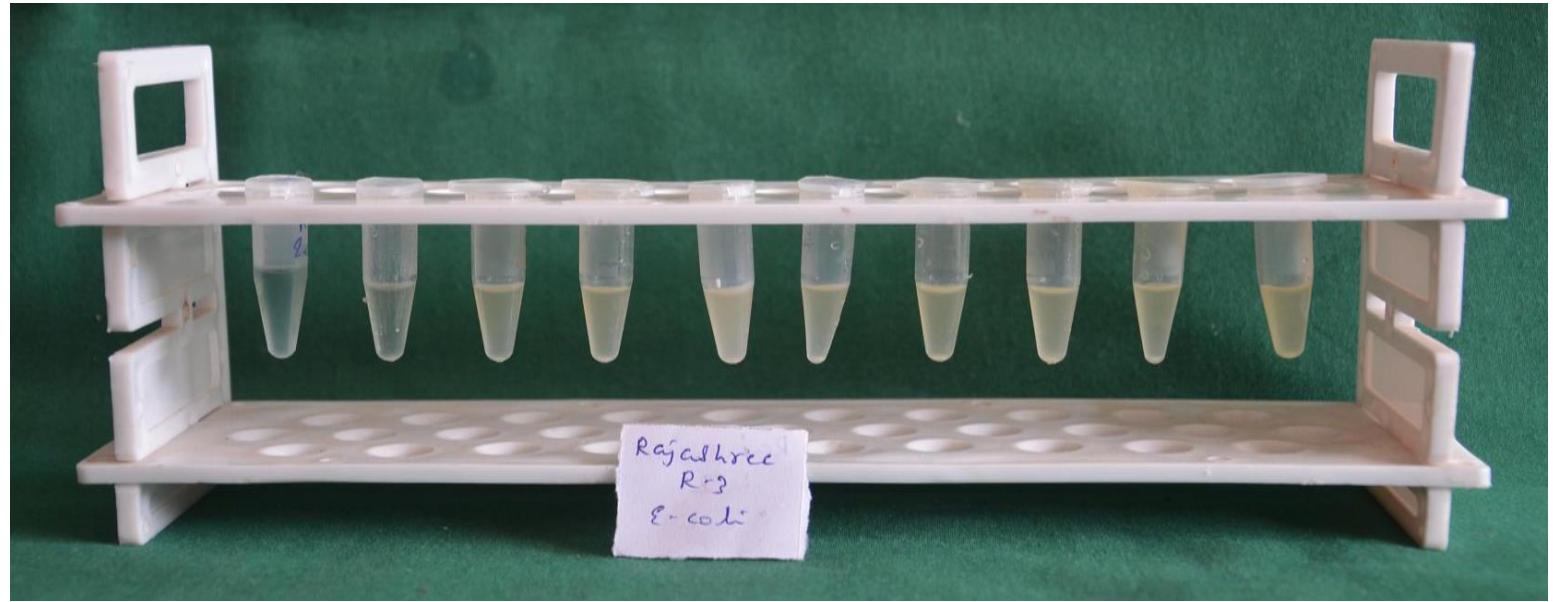

Fig. 10. Shows the selective and resistivity of as prepares complex for E.coli

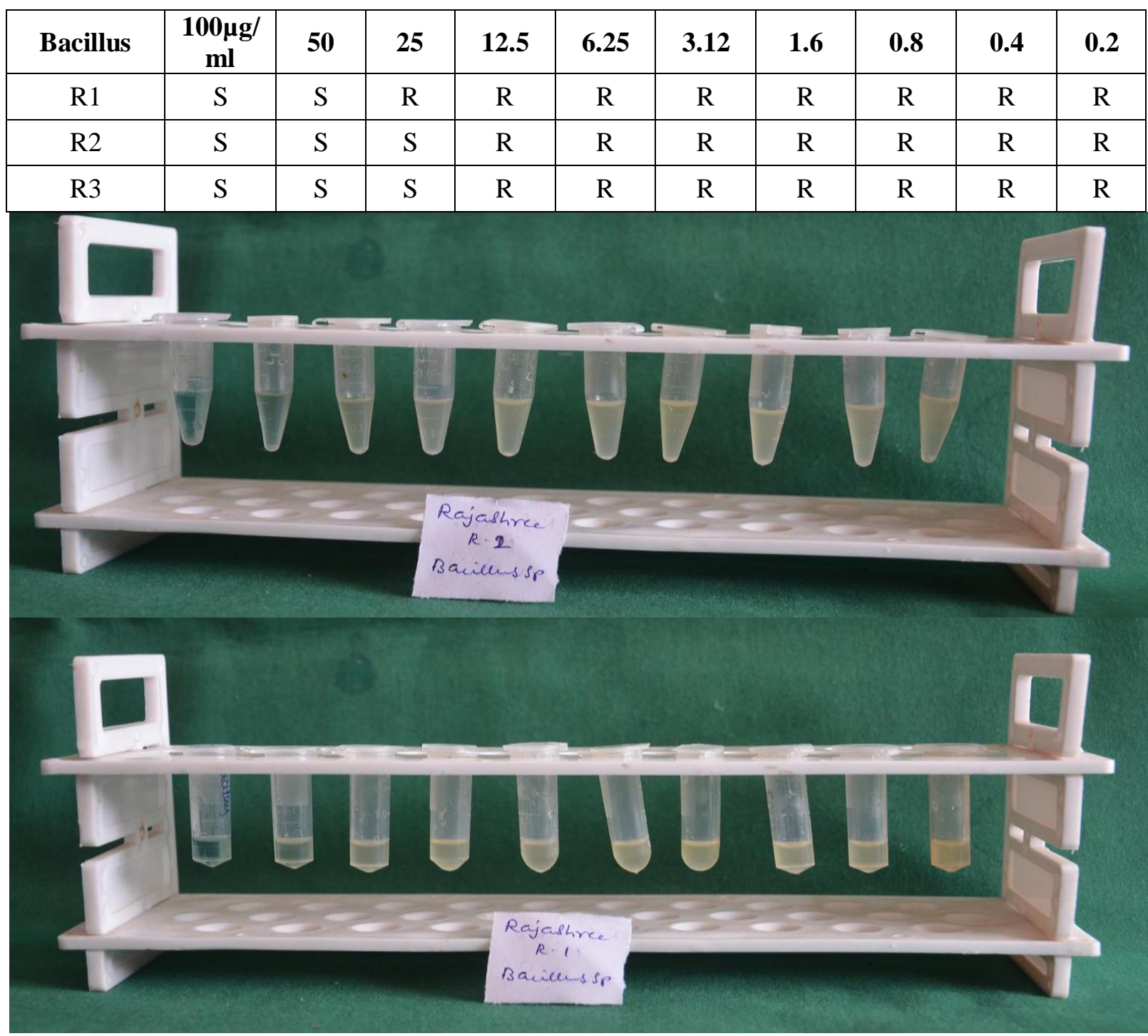

914 J. Chem. Bio. Phy. Sci. Sec. A, August 2017 - Detaber, 2017, Val. 7, №. 4; 906 6-918. DOI:10.24214/jcbps.A.7.4.90618.] 


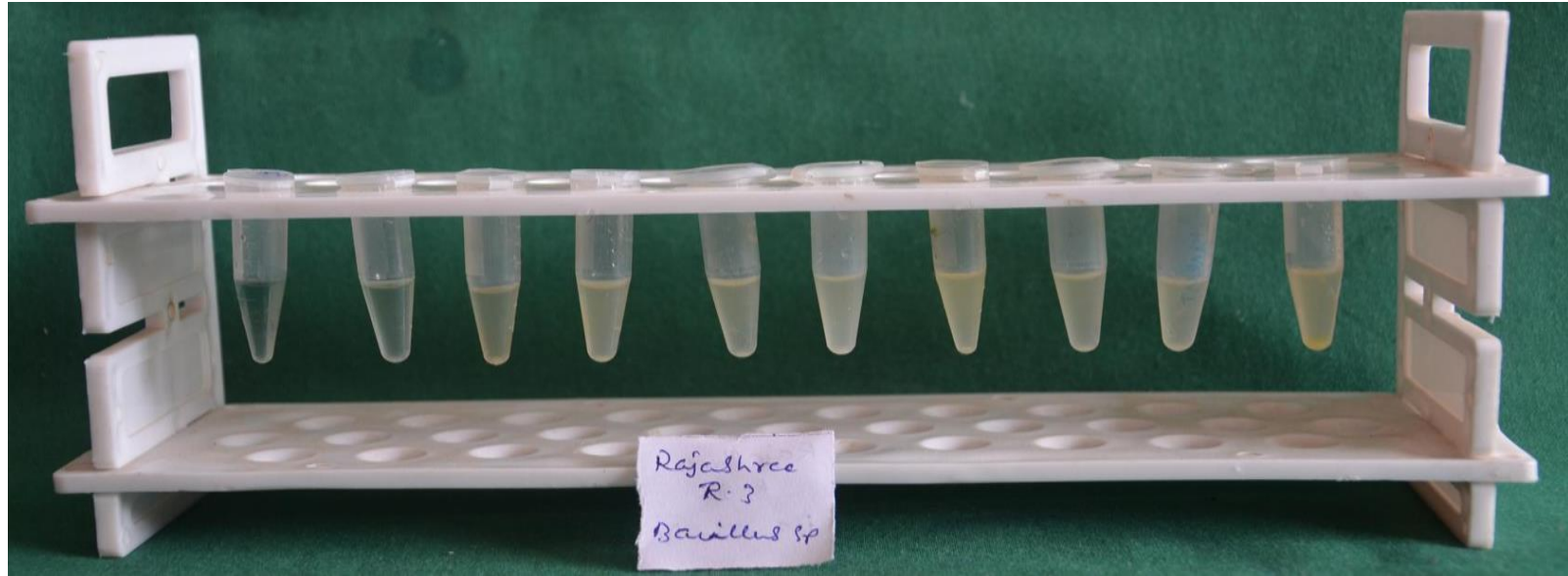

Fig. 11. Shows the selective and resistivity of as prepares complex for bacteria bacillus

\begin{tabular}{|c|c|c|c|c|c|c|c|c|c|c|}
\hline A.niger & $\mathbf{1 0 0} \boldsymbol{\mu g} / \mathbf{m l}$ & $\mathbf{5 0}$ & $\mathbf{2 5}$ & $\mathbf{1 2 . 5}$ & $\mathbf{6 . 2 5}$ & $\mathbf{3 . 1 2}$ & $\mathbf{1 . 6}$ & $\mathbf{0 . 8}$ & $\mathbf{0 . 4}$ & $\mathbf{0 . 2}$ \\
\hline $\mathrm{R} 1$ & $\mathrm{~S}$ & $\mathrm{~S}$ & $\mathrm{~S}$ & $\mathrm{~S}$ & $\mathrm{~S}$ & $\mathrm{~S}$ & $\mathrm{R}$ & $\mathrm{R}$ & $\mathrm{R}$ & $\mathrm{R}$ \\
\hline $\mathrm{R} 2$ & $\mathrm{~S}$ & $\mathrm{~S}$ & $\mathrm{~S}$ & $\mathrm{R}$ & $\mathrm{R}$ & $\mathrm{R}$ & $\mathrm{R}$ & $\mathrm{R}$ & $\mathrm{R}$ & $\mathrm{R}$ \\
\hline $\mathrm{R} 3$ & $\mathrm{~S}$ & $\mathrm{~S}$ & $\mathrm{~S}$ & $\mathrm{R}$ & $\mathrm{R}$ & $\mathrm{R}$ & $\mathrm{R}$ & $\mathrm{R}$ & $\mathrm{R}$ & $\mathrm{R}$ \\
\hline
\end{tabular}

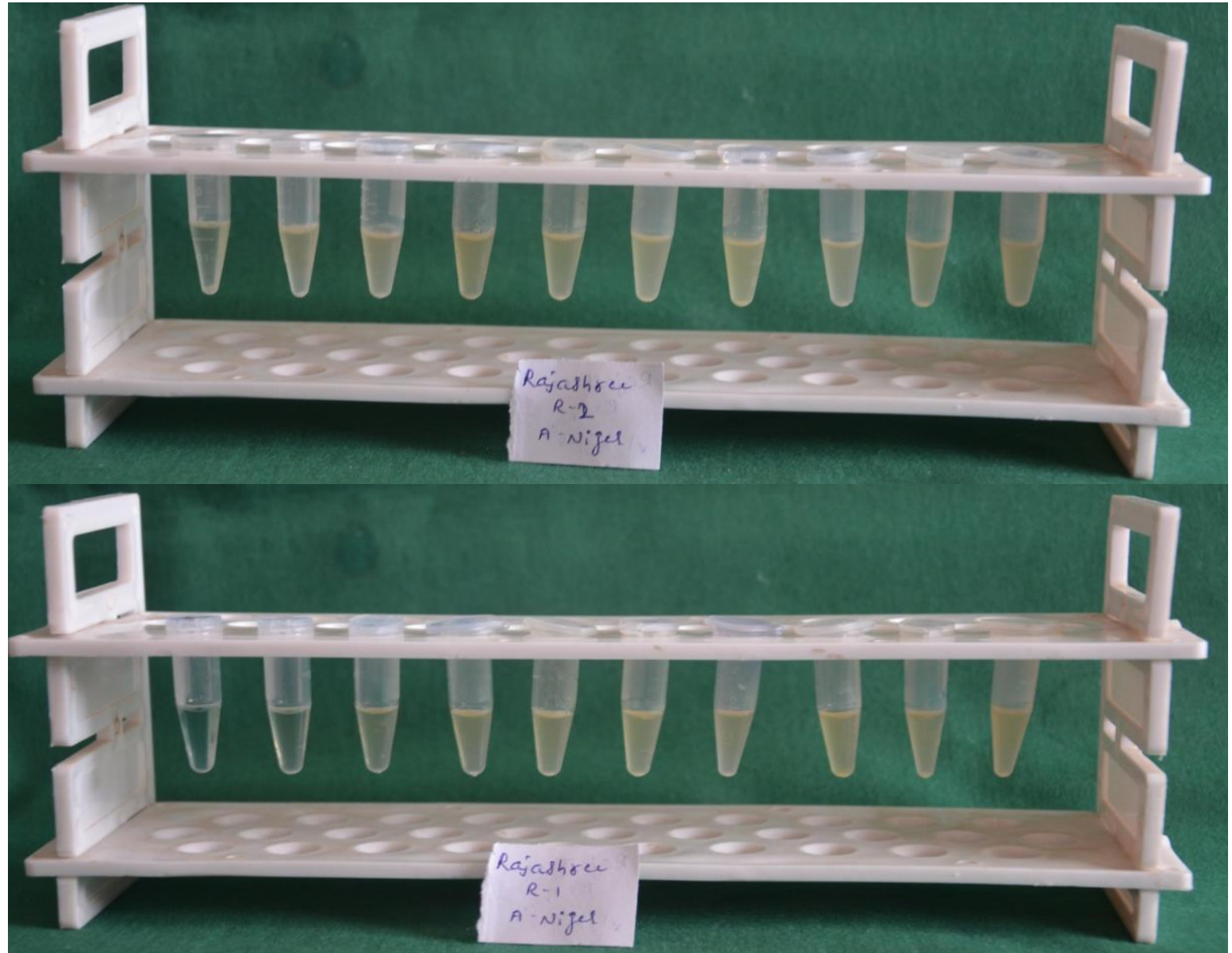

915 J. Chem. Bio. Phy. Sci. Sec. A, August 2017 - Dctober, 2017, Val. 7, №. 4; 900 -918. DOI:10.24214/jcbps.A.7.4.90618.] 


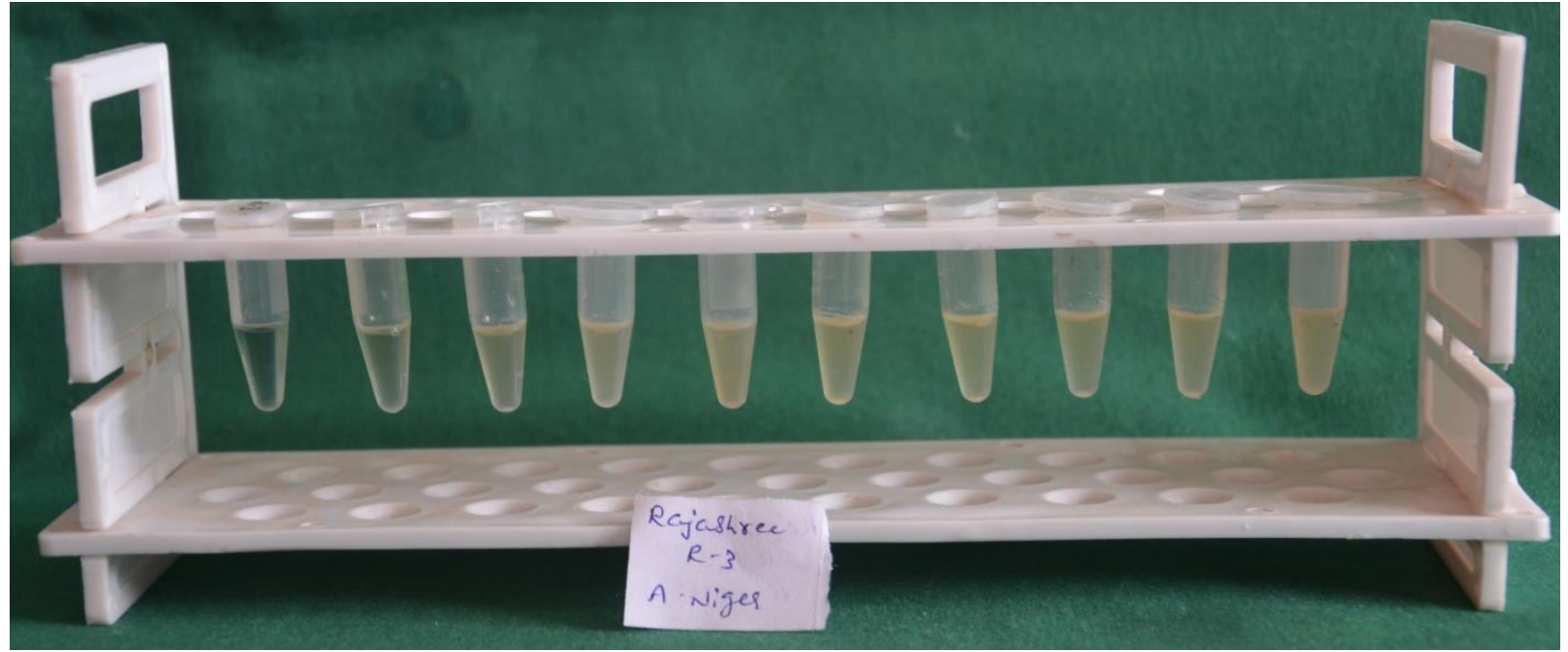

Fig. 12. Shows the selective and resistivity of as prepares complex for Aspergillus niger

\begin{tabular}{|c|c|c|c|c|c|c|c|c|c|c|}
\hline A.flavus & $\mathbf{1 0 0} \boldsymbol{\mu g} / \mathbf{m l}$ & $\mathbf{5 0}$ & $\mathbf{2 5}$ & $\mathbf{1 2 . 5}$ & $\mathbf{6 . 2 5}$ & $\mathbf{3 . 1 2}$ & $\mathbf{1 . 6}$ & $\mathbf{0 . 8}$ & $\mathbf{0 . 4}$ & $\mathbf{0 . 2}$ \\
\hline R1 & $\mathrm{S}$ & $\mathrm{S}$ & $\mathrm{S}$ & $\mathrm{S}$ & $\mathrm{S}$ & $\mathrm{S}$ & $\mathrm{S}$ & $\mathrm{S}$ & $\mathrm{S}$ & $\mathrm{R}$ \\
\hline $\mathrm{R} 2$ & $\mathrm{~S}$ & $\mathrm{~S}$ & $\mathrm{~S}$ & $\mathrm{~S}$ & $\mathrm{~S}$ & $\mathrm{~S}$ & $\mathrm{~S}$ & $\mathrm{~S}$ & $\mathrm{~S}$ & $\mathrm{R}$ \\
\hline $\mathrm{R} 3$ & $\mathrm{~S}$ & $\mathrm{~S}$ & $\mathrm{~S}$ & $\mathrm{~S}$ & $\mathrm{~S}$ & $\mathrm{~S}$ & $\mathrm{~S}$ & $\mathrm{~S}$ & $\mathrm{~S}$ & $\mathrm{R}$ \\
\hline
\end{tabular}

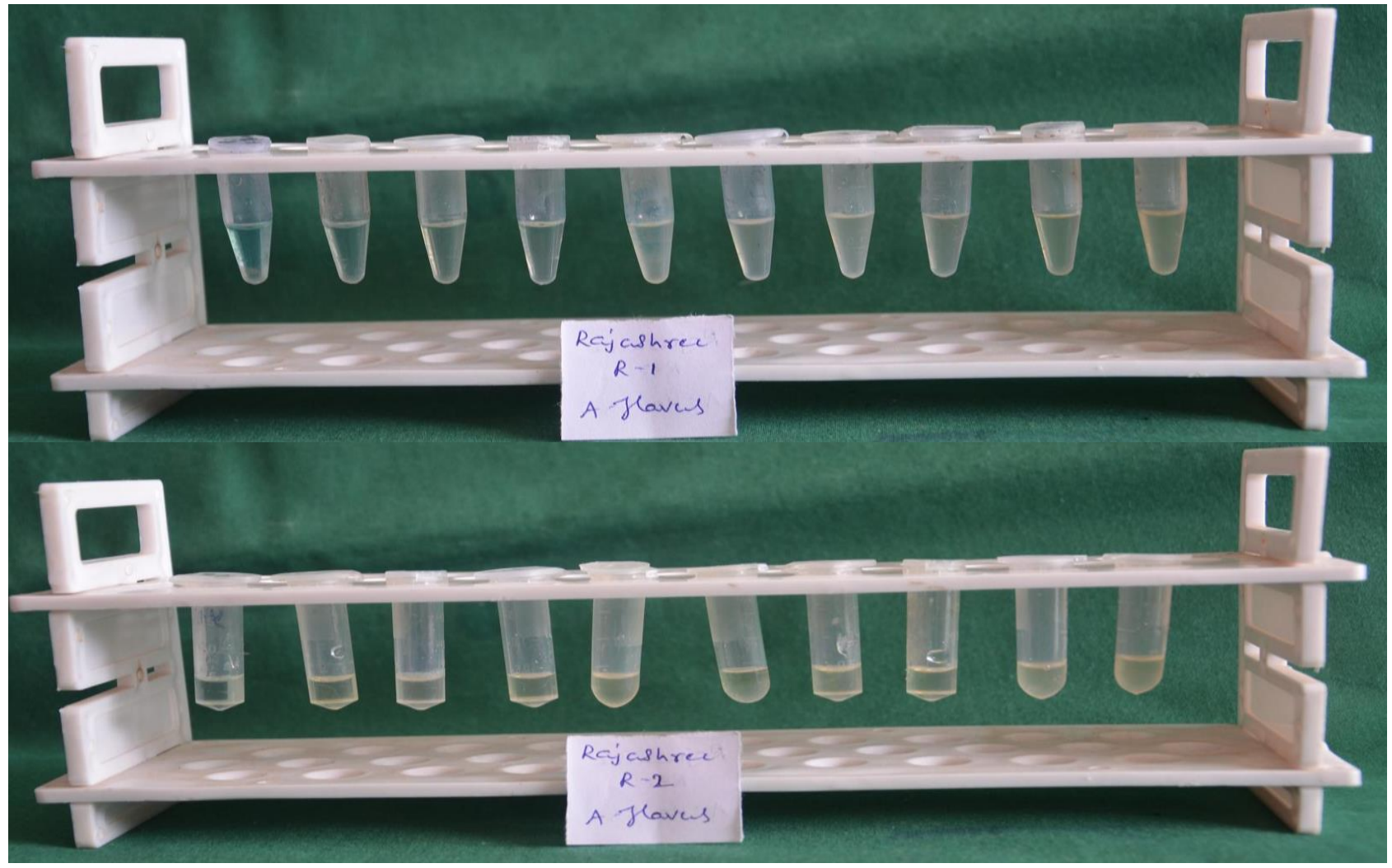

916 J. Chem. Bio. Phy. Sci. Sec. A, August 2017 - Detaber, 2017, Val. 7, №. 4; 906 -918. DOI:10.24214/jcbps.A.7.4.90618.] 


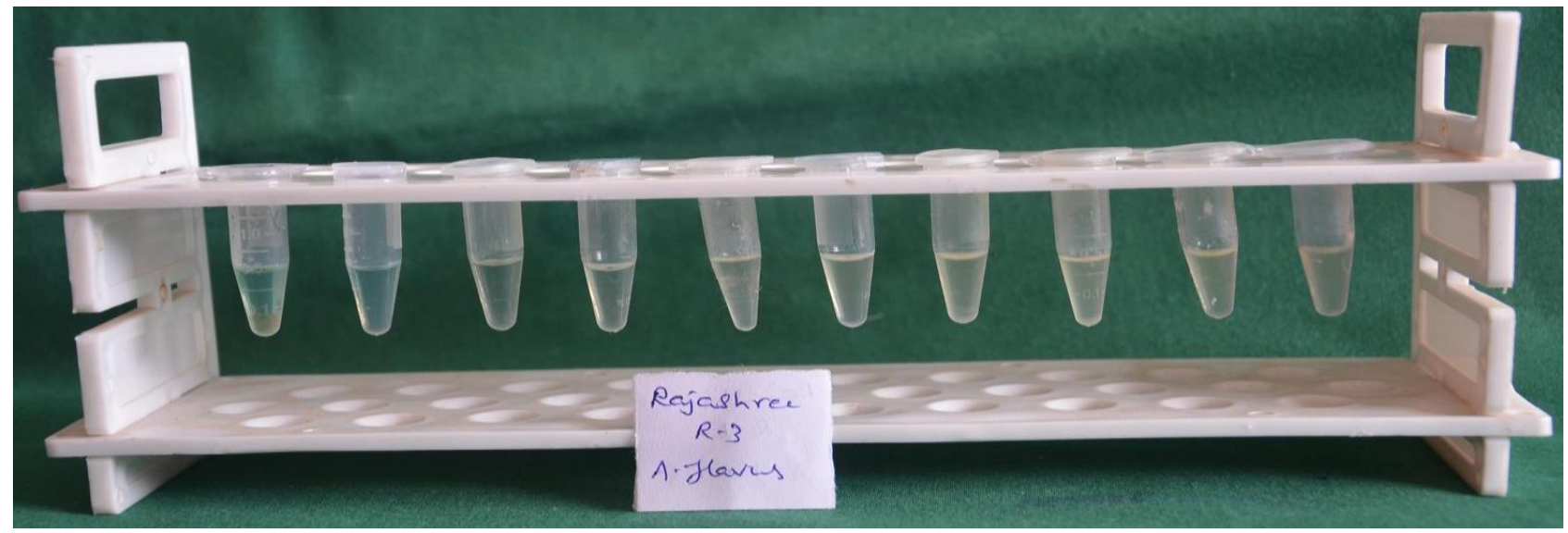

Fig. 13. Shows the selective and resistivity of as prepares complex for Aspergillus flavus<smiles>CN1c2[nH]c(=O)[nH]c(=O)c2N(C)C1C1N(C)c2c(n(C)c(=O)n(C)c2=O)N1C</smiles>

Fig.14. shows the predicted complex structure of copper- caffeine

\section{CONCLUSION}

We have been able to synthesis and characterize complex containing caffeine coordinated with $\mathrm{Cu}(\mathrm{II})$. The interaction of caffeine with transition metal ions was yield to mixed ligand complexes of the type Cu-caffeine. From the results obtained by XRD, UV-Vis and FTIR indicate the formation of copper-caffeine complex. Antibacterial activity results reveal that, copper is an electron acceptor it reduces the capacity of bacterial growth. Aspergillus flavus fungus has the less capacity to substitute oxygen with alternative oxidisable compounds as terminal electron acceptor in respiration, so it shows highly sensitive up to $0.2 \mathrm{gm} / \mathrm{L}$.

\section{ACKNOWLEDGEMENT}

We thank the Rani Channamma University for supporting to carry out this work and authors thank to Vision Group on Science and Technology, Govt. of Karnataka for financial assistance.

\section{REFERENCES}

1. J. Ajit, P. Abhishek, K. Asheesh, Res. J. Forensic Sci., 2012, 1, 8-14

2. N. Thangaraj, S. Sharan, V. Suneetha, Res. J. Rec. Sci., 2012, 2, 33-40

3. K. Satindar, D. P. Chattopadhyay, V. Kaur, Res. J. Eng. Sci., 2012, 1, 21-26

4. Tragonos, J. Kapuscinski, Z. Darzynkiewicz, Cancer Res., 1991, 51, 3682-3689

5. D. B. Davies, D. A. Veselkov, L. N. Djimant, A. N. Veselkov, Eur. Biophys. J., 2001, 30, 354-366

6. C. A. Lipinski, F. Lombardo, B. W. Dominy, P. J. Feeney, Adv. Drug Delivery Rev., 2001, 46, 3-26 
7. J. V. Quaglian, J. Fujita, G. J. Franz, Am. Chem. Soc., 1961, 81, 3770-3774

8. S. Einar, Acta Cryst. 1969, 25, 1480-1486

9. H. A. Neville, G. A. Trevor, R. H. John, F. K. Gregory, J. M. Ian, J.C.S. Chem. Comm., 1979, 8, 324-329

10. L. Amane Mohamed, E. L. Hamdani Hicham, Res. J. Chem. Sci., 2014, 4, $42-47$

11. D. Daurio, C. Medina, R. S. Karthik, F. Alvarez-Nunez, Pharmaceutics, 2011, 3, 582-587

12. M. Muschol, B. R. Dasgupta, B. M. Salzberg, Biophy. J., 1999, 77, 577-581

13. D. S. Murry, P. J. Hansen, J. Chem. Educ., 1995, 72, 851-856

14. A.J. Hampp, J. Chem. Educ., 1996, 73, 1172-1177

\section{Corresponding author: Vidyasagar. C. C}

${ }^{1}$ Department of Chemistry, Rani Channamma University, Belgaum-591156, India

On line publication Date: 31.8.2017 